\title{
ANALISIS PERTUMBUHAN MINDI (Melia azedarach L) DAN PRODUKTIVITAS UMBI GARUT (Maranta arundinacea dan Maranta linearis L) DALAM SISTEM AGROFORESTRI
}

\author{
Growth Analysis of Mindi (Melia azedarach $L$ ) and Productivity of Arrowroot (Maranta \\ arundinacea and Maranta linearis L) in Agroforestry System
}

Triaty Handayani $^{1}$, Nurheni Wijayanto ${ }^{2}$, dan Arum Sekar Wulandari ${ }^{2}$

(Diterima Mei 2018 / Disetujui Juli 2018)

\begin{abstract}
Agroforestry system has been considered as one of the effective ways of the plantation for increasing a production and securing the environment as well as plays an important role in the social and economic development. Mindi development has been widely practiced in community forests but the agroforestry system is only limited to local knowledge obtained from old generation. This causes the people's forests to tend to be unable to survive due to the demands of the people's food needs. Arrowroot (Maranta arundinacea L.) had an important crop as a potential source of food and substitute for wheat flour and potential to be planted under Mindi trees (Melia azedarach L.) which had also potential as an alternative tree planting for the community forest. This research was aimed to 1) analyze the growth of Mindi trees and the productivity of arrowroot under mindi trees compared to monoculture system, 2) analyze the nutrient content of arrowroot under mindi trees compared to monoculture system. The experiment used a complete randomized design (CRD) with the agroforest under mindi trees and monoculture system as a factor. The result of growth in mindi showed that there is no significant difference in height, diameter, and canopy variable in agroforestry and monoculture plantation system while the root variable had significant difference among agroforestry and monoculture system. The physicochemical and nutrients content of arrowroot were diverse whereas there is no significant difference between the two system tested.
\end{abstract}

Keywords: agroforestry, growth, productivity, fisikokimia, soil nutrient

\section{PENDAHULUAN}

\section{Latar Belakang}

Agroforestri merupakan salah satu sarana yang efektif untuk pemerataan dan tahapan untuk mengatasi kemiskinan di lingkungan masyarakat desa hutan, juga bisa meningkatkan pendapatan dan produski pangan. Pengembangan agroforestri, mempunyai prospek yang cukup baik dalam konstribusinya terhadap peningkatan pendapatan petani sehingga mempermudah akses terhadap pangan, di samping menjaga keamanan dan kelestarian hutan bersama masyarakat atau petani di sekitar hutan (Mayrowani 2011).

Pemilihan mindi (Melia azedarach L.) sebagai jenis alternatif dalam pembangunan hutan tanaman khususnya hutan rakyat tentunya sangat potensial. Mindi terbukti telah dikembangkan sebagai jenis alternatif dalam pembangunan hutan tanaman di Perum Perhutani. Hal ini tentunya disebabkan prospek mindi sebagai salah satu fast growing species yang potensial dikembangkan dalam pengembangan hutan tanaman ke depan (Sudomo 2011). Mindi adalah salah satu jenis tanaman cepat tumbuh dari suku Meliaceae. Mindi termasuk dalam kelas kuat II-III dan kelas awet VI-V. Jenis ini memiliki kayu yang berkualitas baik dan sudah

\footnotetext{
${ }^{1}$ Mahasiswa Pascasarjana Program Studi Silvikultur Tropika Departemen Silvikultur Fakultas Kehutanan IPB

${ }^{2}$ Staf Pengajar Departemen Silvikultur Fakultas Kehutanan IPB
}

banyak dikembangkan pada hutan rakyat khususnya di Jawa-Madura (Syasuwida 2012). Kayu mindi dapat digunakan dalam industri rumah tangga masyarakat sebagai bahan bangunan dan bahan baku mebel seperti meja, lemari dipan dan lain-lain.

Garut (Maranta arundinacea L.) merupakan sumber bahan pangan potensial pengganti tepung terigu. Garut mempunyai potensi pasar internasional di St. Vincent (Amerika Tengah). Tanaman ini telah diusahakan secara komersial dan sekitar 95\% kebutuhan dunia dipasok dari Amerika Tengah. Negara pengekspor garut di kawasan Asia Tenggara adalah Filipina. Tepungnya berkualitas tinggi, berukuran halus dan harganya mahal. Tanaman garut di Indonesia belum dibudidayakan secara intensif, oleh karena itu perlu pemasyarakatan penggunaan bahan baku garut serta budidayanya (Amalia 2014; Koswara 2013).

Secara ekologi tanaman garut memerlukan iklim panas dan kondisi basah. Garut dapat tumbuh pada ketinggian 0 sampai $900 \mathrm{mdpl}$, tetapi paling baik pada ketinggian 60 sampai $90 \mathrm{~m}$ dpl dengan tanah berpasir. Tanah harus diolah dan dibajak dengan baik, serta diberi pupuk terlebih dahulu (Suhardi et al. 1999). Tanaman garut dapat hidup dan berkembang di bawah naungan, sehingga diperlukan penelitian tentang hubungan interaksi dari komponen penyusun agroforestri dan pertumbuhan jenis penyusunnya, untuk menemukan produktivitas terbaik.

Tanaman garut dapat dijumpai di berbagai daerah seperti Pulau Jawa, Maluku, dan Sulawesi. Kandungan 
karbohidrat dalam bentuk pati yang cukup tinggi dapat menjadi sumber karbohidrat alternatif. Tanaman garut merupakan salah satu kekayaan alam dan banyak ditanam di lingkungan masyarakat Indonesia serta memiliki potensi pengembangan pangan lokal sangat besar. Selama ini produk olahan pangan lokal tersebut dibuat skala industri rumah tangga, tetapi dengan sentuhan teknologi dapat bersaing dan layak ekspor (Djaafar 2010).

Rambey (2011) menyatakan sejauh ini penduduk melakukan pola hutan rakyat mindi secara turun menurun dan sebatas pengetahuan lokal. Pengelolaan hutan rakyat mindi secara berkelanjutan dapat dilakukan dengan memadukan tanaman pertanian yang dapat meningkatkan nilai ekonomi masyarakat, salah satunya adalah umbi garut. Umbi garut dapat menggantikan pasokan tepung terigu karena memiliki komposisi yang hampir sama dengan tepung terigu, namun umbi garut belum dibudidayakan oleh masyarakat Indonesia secara intensif. Komponen dalam sistem agroforestri baik tanaman kehutanan dan pertanian sebagai tanaman tumpang sari diharapkan memberikan interaksi yang positif. Pemilihan tanaman mindi dan umbi garut diharapkan menjadi kombinasi yang tepat. Kendala utama yang ditemukan dalam pengelolaan lahan secara agroforestri yaitu adanya persaingan baik air, unsur hara, dan cahaya. Penelitian agroforestri mindi dan umbi garut dilakukan untuk menguji interaksi dalam pertumbuhan dan produktivitasnya. Tujuan penelitian ialah untuk 1). menganalisis pertumbuhan mindi dan produktivitas umbi garut dalam sistem agroforestri dan monokultur, 2). menganalisis kandungan unsur hara umbi garut dalam sistem agroforestri dan monokultur, dan 3). menganalisis fisikokimia umbi garut dalam sistem agroforestri dan monokultur.

\section{METODE PENELITIAN}

\section{Waktu dan Tempat Penelitian}

Penelitian dilaksanakan pada bulan Mei 2017 sampai Desember 2017. Penelitian dilaksanakan di Unit Konservasi Budidaya Biofarmaka Cikabayan Kampus IPB, Darmaga. Koordinat lokasi penelitian berada pada $106^{\circ} 43$ '0.81” BT, 6032”51.95” LS.

\section{Bahan}

Bahan-bahan yang digunakan dalam penelitian ini adalah pupuk kandang kambing, pupuk kandang ayam, tegakan mindi (Melia azedarach), bibit umbi garut (Maranta arundinacea dan Maranta linearis).

\section{Alat}

Alat-alat yang digunakan adalah cangkul, golok, gelas ukur, bor tanah, pita ukur, penggaris, ring tanah, timbangan, GPS, kompas, luxmeter, haga hypsometer, kaliper, termohigrometer, label, karung, sprayer, gunting, kamera digital, bambu, paku, plastik, tali, tampah, gunting, tally sheet, dan alat tulis.

\section{Prosedur Analisis Data}

$\underline{\text { Pengambilan sampel tanah }}$

Sampel tanah diambil dari petak tegakan tanaman mindi dan petak monokultur umbi garut. Pengambilan sampel tanah dengan metode systematic sampling (SyS) (Suganda et al. 2014). Pengambilan sampel tanah masing-masing 5 sampel menggunakan metode tanah terusik dan metode tanah utuh.

\section{Penelitian 1: Pertumbuhan tanaman mindi pada pola tanam agroforestri dan monokultur}

Tanaman mindi yang digunakan berada di Unit Konservasi Budidaya Biofarmaka Cikabayan IPB, berumur 3 tahun dengan jarak tanam $2.5 \mathrm{~m} \times 2.5 \mathrm{~m}$. Luasan lahan $\pm 300 \mathrm{~m}^{2}$. Tanaman sampel mindi yang digunakan pada lahan agroforestri dan monokultur masing-masing 6 sampel.

\section{a. Pengambilan data dan pengamatan dimensi mindi}

1. Pengukuran tinggi

Pengukuran pertumbuhan tinggi mindi menggunakan hagahypsometer, mindi diukur mulai dari leher akar sampai titik tumbuhnya dilakukan setiap 1 bulan sekali sampai bulan ke-6.

2. Pengukuran diameter batang

Pengukuran diameter batang menggunakan pita meter, diukur pada ketinggian $130 \mathrm{~cm}$ di atas pangkal batang mindi dilakukan setiap 1 bulan sekali sampai bulan ke-6.

3. Pengukuran tajuk

Pengukuran tajuk menggunakan pita meter, diukur panjang dan lebar tajuk pada proyeksi tajuk yang akan diamati. Menurut Wijayanto dan Nurunnajah (2012) pengukuran tajuk dilakukan untuk mengetahui luas tajuk. Pengukuran tajuk sebanyak 6 pohon dilakukan saat awal dan akhir penanaman umbi garut.

4. Pengukuran akar

Pengambilan data dilakukan pada akar mindi yang terdapat pada kedalaman $0-20 \mathrm{~cm}$. Penggalian tanah akan dihentikan apabila pada kedalaman 0-20 $\mathrm{cm}$ telah di temukan akar mindi.

\section{b. Rancangan Penelitian}

Penelitian dilakukan dengan menggunakan rancangan acak lengkap (RAL) satu faktor yaitu pola tanam, terdiri atas 2 taraf yaitu agroforestri (P0) dan monokultur (P1) dengan 6 ulangan. Model rancangan yang digunakan adalah sebagai berikut (Mattjik dan Sumertajaya 2013):

$$
\mathrm{Y}_{\mathrm{ij}}=\mu+\tau_{\mathrm{i}}+\varepsilon_{\mathrm{ij}}
$$

Data hasil penelitian dianalisis dengan menggunakan sidik ragam (ANOVA) pada taraf nyata $5 \%$ untuk mengetahui perbedaan antar perlakuan. Data diolah menggunakan software SAS 9.1, jika:

a. $\mathrm{P}$-value $>\alpha$ (0.05), maka perlakuan tidak memberikan pengaruh nyata terhadap parameter yang diamati. 
b. P-value $<\alpha(0.05)$, maka perlakuan memberikan pengaruh nyata terhadap parameter yang diamati, kemudian dilanjutkan dengan uji jarak berganda Duncan's Multiple Range Test.

\section{Penelitian 2: Produktivitas garut pada pola tanam agroforestri dan monokultur}

\section{a. Penyiapan lahan dan pembuatan lubang tanam}

Persiapan lahan dimulai dengan kegiatan pembersihan lahan dari tanaman liar dan gulma dilakukan 2 minggu sebelum penanaman. Tanah kemudian diolah menggunakan cangkul hingga gembur dan dibuat bedengan. Tanah yang telah dibuat bedengan dicampur dengan pupuk kandang kambing dengan dosis $175 \mathrm{~kg} /$ ha (Ariyantoro 2014) dan pupuk kandang ayam dengan dosis $90 \mathrm{~kg} / \mathrm{ha}$ (Sarno 2009) kemudian dibuat lubang tanam.

Bedengan yang dibuat berukuran $1.5 \mathrm{~m} \mathrm{x} 3 \mathrm{~m}$ dengan ketinggian $\pm 30 \mathrm{~cm}$. Jarak antar tanaman mindi dan bedengan adalah $50 \mathrm{~cm}$, jarak tanam $50 \times 50 \mathrm{~cm}$ sehingga terdapat 18 lubang tanam dalam satu ulangan.

\section{b. Persiapan bibit}

Bibit garut berupa umbi diperoleh dari Balai Penelitian Tanaman Obat dan Aromatik, Bogor. Umbi garut diperbanyak secara vegetatif, menggunakan rhizoma dengan panjang $\pm 5 \mathrm{~cm}$. Rhizoma diambil dari bibit yang sehat, tidak kurus, dan tidak terkena penyakit. Rhizoma ditanam pada tampah dengan media tanah, pupuk kandang dan pasir $(2: 1: 1 \mathrm{v} / \mathrm{v} / \mathrm{v})$. Setelah rhizoma bertunas sepanjang 1-2 cm dapat dipindahkan ke lahan penanaman.

\section{c. Penanaman}

Rhizoma yang sudah bertunas ditanam pada lubang tanam yang telah disediakan. Pemeliharaan dilakukan dengan menyiangi gulma seminggu sekali.

\section{d. Panen}

Panen dilakukan pada saat umur tanaman 6 dan 8 bulan setelah tanam. Proses pemanenan yang dilakukan meliputi pencabutan umbi, pembersihan, dan pemotongan batang serta daunnya yang selanjutnya diamati karakter fisik dan pengukuran bobotnya.

\section{Rancangan Penelitian}

Penelitian menggunakan rancangan petak terbagi (split plot design). Petak utamanya adalah pola tanam yang terdiri atas 2 taraf yaitu monokultur (P0) dan agroforestri (P1). Anak petaknya adalah jenis tanaman garut, terdiri atas Maranta arundinacea dan Maranta linearis.

Percobaan ini memiliki 4 kombinasi yang diulang sebanyak 9 kali sehingga terdapat 36 satuan percobaan. Ukuran petak percobaan $1.5 \mathrm{~m}$ x $3 \mathrm{~m}$ dengan jarak tanam yang digunakan $50 \mathrm{~cm}$ x $50 \mathrm{~cm}$. Model rancangan yang digunakan adalah sebagai berikut (Mattjik dan Sumertajaya 2013):

$$
Y i j k=\mu+\alpha i+\beta j+(\alpha \beta) i j+\delta i k+\varepsilon j k
$$

Data hasil penelitian dianalisis dengan menggunakan sidik ragam (ANOVA) pada taraf nyata 5\% untuk mengetahui perbedaan antar perlakuan. Data diolah menggunakan software SAS 9.1, jika:

a. P-value $>\alpha$ (0.05), maka perlakuan tidak memberikan pengaruh nyata terhadap parameter yang diamati

b. P-value $<\alpha(0.05)$, maka perlakuan memberikan pengaruh nyata terhadap parameter yang diamati, kemudian dilanjutkan dengan uji jarak berganda Duncan's Multiple Range Test.

\section{Penelitian 3: Analisis fisikokimia umbi garut dalam pola agroforestri dan monokultur}

Analisis kadar air dengan metode langsung dilakukan dengan cara mengeluarkan air dari bahan pangan dengan bantu pengering oven, desikasi, destilasi, ekstraksi, fisika dan kimia. Metode ini mempunyai ketelitian yang tinggi, tetapi pada umumnya memerlukan watu pengerjaan yang relatif lama karena pengerjaannya kebanyakan bersifat manual. Metode analisis pati garut diekstraksi dengan cara basah. Ekstraksi pati garut cara basah terdiri atas tahapan pembersihan, pengupasan, pencucian, perendaman, dan penghancuran umbi garut, yang dilanjutkan dengan tahap proses pemisahan pati melalui penyaringan, pengayakan, pengendapan dan pencucian. Pati garut basah yang diperoleh kemudian dikeringkan, digiling, dan diayak. Proses ekstraksi cara basah tersebut menghasilkan rendemen pati garut. Alkohol hasil ekstrasi diambil untuk mengukur kadar gula sedangkan untuk pengukuran pati diambil endapannya dengan cara hidrolisis.

\section{Data pendukung} adalah:

Data pendukung yang diperlukan dalam penelitian

a. Iklim

Data iklim diperoleh dari Stasiun Klimatologi Kelas I Darmaga Bogor, Jalan alternatif IPB, Situ Gede Bogor Barat.

b. Pengukuran intensitas cahaya

Intensitas cahaya diukur dengan alat lux meter. Pengukuran masing-masing dilakukan pada tiga titik yang berbeda pada pola tanam umbi garut monokultur dan agroforestri, tiga kali dalam sehari yaitu pagi, siang, dan sore dilakukan tiap minggu. Alat tersebut dipegang setinggi $75 \mathrm{~cm}$ di atas lantai hutan.

c. Pengukuran suhu dan kelembaban

Pengukuran suhu dan kelembaban dengan menggunakan termohigrometer. Pengukuran masing-masing dilakukan pada tiga titik yang berbeda pada pola tanam umbi garut monokultur dan agroforestri, tiga kali dalam sehari yaitu pagi, siang, dan sore dilakukan tiap minggu.

\section{HASIL DAN PEMBAHASAN}

1. Pertumbuhan tanaman mindi pada pola tanam agroforestri dan monokultur

Pertumbuhan pada tanaman merupakan salah satu indikator keberhasilan pengelolaan tanaman. Dimensi tanaman menjadi peubah penting untuk mengetahui 
interaksi dan persaingan yang ada pada suatu lahan dalam sistem agroforestri. Peubah dimensi yang diamati pada mindi meliputi tinggi, diameter, tajuk, dan akar pohon (Wardani 2017).

Pertumbuhan mindi dalam pola tanam agroforestri dan monokultur pada peubah tinggi, diameter, dan tajuk tidak memberikan perbedaan yang nyata sedangkan pada peubah akar memberikan pengaruh yang nyata pada pertumbuhan mindi (Tabel 1). Hal ini diduga karena akar merupakan awal pertumbuhan suatu benih. Noordwijk et al. (2003) menyatakan bahwa semua helai daun mentranspirasikan sejumlah air, oleh karena itu diperlukan akar untuk menyerap air dan hara dari dalam tanah. Semakin banyak jumlah helai daun per cabang maka semakin banyak jumlah air yang harus diangkut dari dalam tanah, berarti semakin besar diameter cabang yang dibutuhkan. Tinggi tanaman merupakan komponen penting dalam pertumbuhan karena menentukan respon tanaman terhadap pengaruh lingkungan atau perlakuan yang diberikan (Jirmanova et. al. 2016).

Penerapan sistem agroforestri, tanaman pertanian atau tanaman sela yang disisipkan diantara tanaman pokok (kayu) dapat mengurangi kemungkinan terjadinya pencucian atau erosi. Tanaman pertanian umumnya dipilih jenis yang mampu beradaptasi dengan kondisi biofisik lahan, memiliki harga pasar, dan bernilai ekonomis tinggi. Hal ini disebabkan masingmasing individu tanaman pada sistem agroforestri berinteraksi sehingga dapat berdampak positif maupun negatif terhadap pertumbuhan tanaman pokok maupun tanaman semusim (Wijayanto et al. 2010). Pertumbuhan mindi monokultur dan agroforestri.

Pengujian berpengaruh nyata terhadap pengukuran akar, hal ini diduga adanya interaksi positif bagi pohon mindi yang dikombinasi dengan umbi garut. Tanaman semusim menyebabkan keadaan tumbuh menjadi lebih baik. Salah satu faktor yang memengaruhi pertumbuhan tanaman adalah tanah yang memiliki kandungan unsur hara yang cukup dan aerasi yang baik Tabel 2 dan Tabel 3 .

Tabel 2 menunjukkan Porositas tanah dan ketersediaan air termasuk dalam kategori rendah (LPT 1983), namun di dalam pola agroforestri lebih besar dibandingan yang lain. Jauhari et. al. (2016) menyatakan bahwa pertumbuhan mindi pada pola tanam agroforestri lebih baik dibandingkan dengan monokultur. Bulk density tertinggi pada pola tanam monokultur mindi yaitu $1.46 \%$ dan Bulk density terendah terdapat pada pola tanam agroforestri yaitu $1.23 \%$. Bulk density merupakan petunjuk kepadatan tanah. Semakin padat suatu tanah makin tinggi bulk density, yang berarti semakin sulit meneruskan air atau ditembus akar tanaman. Porositas tanah tertinggi pada pola tanam agroforestri yaitu $53.47 \%$ dan porositas tanah terendah terdapat pada pola tanam monokultur mindi yaitu $45.06 \%$. Porositas tanah dipengaruhi oleh kandungan bahan organik, struktur tanah, dan tekstur tanah.

Parameter $\mathrm{pH}$ merupakan salah satu parameter penting suatu tanaman dapat tumbuh atau tidak. Semakin rendah $\mathrm{pH}$ tanah maka semakin sulit tanaman untuk tumbuh karena tanah bersifat masam dan mengandung toksik (racun). Sebaliknya, jika $\mathrm{pH}$ tanah tinggi maka tanah bersifat basa dan mengandung kapur. Ketersediaan bahan organik juga saling berkaitan dengan kondisi tekstur tanah, semakin banyak liat maka semakin banyak pula bahan organik yang tersimpan (Oktavia 2014). Beberapa unsur hara yang dianalisis secara umum berada pada kisaran sangat rendah sampai rendah berdasarkan kriteria penilaian sifat kimia tanah (Hardjowigeno 2003).

Tabel 1 Hasil analisis keragaman mindi (Melia azedarach L.) agroforestri dan monokultur

\begin{tabular}{lccc}
\multicolumn{1}{c}{ Peubah } & Uji F & Agroforestri & Monokultur \\
\hline Tinggi $(\mathrm{m})$ & th & $14.06 \mathrm{a}$ & $13.32 \mathrm{a}$ \\
Diameter $(\mathrm{cm})$ & th & $40.28 \mathrm{a}$ & $37.34 \mathrm{a}$ \\
Tajuk $(\mathrm{m})$ & tn & $3.75 \mathrm{a}$ & $2.83 \mathrm{a}$ \\
Akar $(\mathrm{cm})$ & $*$ & $83.67 \mathrm{a}$ & $75.83 \mathrm{~b}$ \\
\hline
\end{tabular}

(tn) : tidak berbeda nyata; $(*)$ : berbeda nyata pada taraf uji 5\%, angka-angka pada baris yang sama yang diikuti oleh huruf yang sama tidak berbeda nyata pada taraf uji 5\% (uji selang berganda Duncan)

Tabel 2 Hasil analisis sifat fisik tanah

\begin{tabular}{|c|c|c|c|c|c|c|}
\hline \multirow[t]{2}{*}{ Lokasi } & \multirow{2}{*}{$\begin{array}{c}\text { Bulk } \\
\text { Density } \\
\left(\mathrm{g} / \mathrm{cm}^{3}\right)\end{array}$} & \multirow[t]{2}{*}{$\begin{array}{c}\text { Porositas } \\
(\%)\end{array}$} & \multicolumn{2}{|c|}{$\begin{array}{c}\text { Kadar Air (\%Volume) pada } \\
\text { F }\end{array}$} & \multirow{2}{*}{$\begin{array}{c}\text { Air } \\
\text { Tersedia } \\
(\%)\end{array}$} & \multirow[t]{2}{*}{ Keterangan } \\
\hline & & & $\mathrm{pF} 2.54$ & $\mathrm{pF} 4.2$ & & \\
\hline Monokultur Mindi & 1.46 & 45.06 & 31.72 & 22.86 & 8.86 & Tanah Rusak \\
\hline Monokultur Garut & 1.38 & 47.82 & 38.12 & 27.00 & 11.09 & Tanah Rusak \\
\hline Agroforestri & 1.23 & 53.47 & 36.42 & 21.88 & 14.53 & Tanah Rusak \\
\hline
\end{tabular}

Sumber: Hasil Analisis Tanah pada Laboratotium Departemen Ilmu Tanah dan Sumberdaya Lahan. Fakultas Petanian. IPB

Tabel 3 Hasil analisis sifat kimia tanah

\begin{tabular}{lcccccc}
\hline \multicolumn{1}{c}{ Lokasi } & $\mathrm{pH} \mathrm{1:5}$ & $\begin{array}{c}\text { Walkley \& } \\
\text { Black }\end{array}$ & Kjeldahl & Bray I & N NH $\mathrm{Oac} \mathrm{Ph} 7.0$ \\
\cline { 2 - 6 } & $\mathrm{H}_{2} \mathrm{O}$ & $\mathrm{C}-$ org $(\%)$ & N-Total $(\%)$ & $\mathrm{P}(\mathrm{ppm})$ & $* \mathrm{~K}(\mathrm{ppm})$ & $\mathrm{KTK}\left(\mathrm{Cmol}^{(*)} / \mathrm{kg}\right)$ \\
\hline Agroforestri & $4: 19$ & 1.74 & 0.19 & 2.98 & 21.06 & 29.09 \\
Monokultur Garut & $4: 23$ & 2.26 & 0.21 & 3.26 & 98.72 & 27.13 \\
Monokultur Mindi & $4: 19$ & 1.88 & 0.17 & 3.48 & 48.61 & 22.68 \\
\hline Sumber: Hasil Analisis Tanah pada Laboratotium Departemen Ilmu Tanah dan Sumberdaya Lahan. Fakultas Petanian. IPB
\end{tabular}




\section{Produktivitas garut pada pola tanam agroforestri dan monokultur}

Dalam penerapan sistem agroforestri, tanaman pertanian atau tanaman sela yang disisipkan diantara tanaman pokok (kayu), dapat mengurangi kemungkinan terjadinya pencucian atau erosi. Tanaman pertanian umumnya dipilih jenis yang mampu beradaptasi dengan kondisi biofisik lahan, memiliki pangsa pasar, dan bernilai ekonomis tinggi. Pemilihan jenis tanaman yang layak diusahakan petani merupakan permasalahan dalam penentuan pola agroforestri. Pola-pola agroforestri akan terbentuk sesuai dengan kombinasi tanaman yang dikembangkan. Pola agroforestri yang berbeda memungkinkan terjadinya perbedaan respon bagi pertumbuhan tanaman pokok (Wijayanto et al. 2010).

Tanaman garut mampu beradaptasi terhadap naungan seperti di bawah tegakan pohon serta di lahan marginal (Djaafar 2010), oleh karena itu tanaman garut berpotensi dikembangkan di lahan hutan atau pekarangan. Nurhayati et al. (2003) menyatakan, tanaman garut dapat tumbuh di tempat yang ternaungi tanpa menurunkan kualitas maupun karakteristik umbi.

Pengamatan pada bentuk umbi rata-rata berbentuk lonjong dan memanjang, warna umbi cream dan warna kulit umbi cokelat muda. Daun merupakan bagian

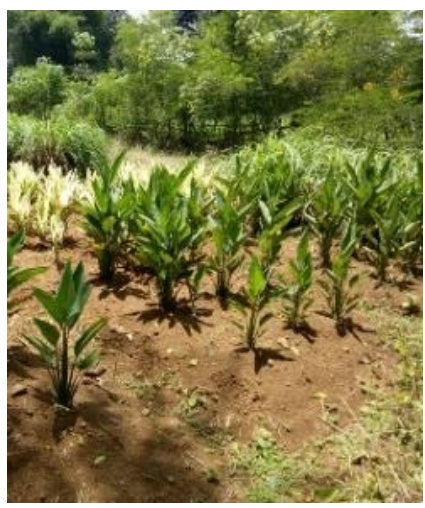

(a) tanaman yang digunakan untuk melakukan fotosintesis. Hasil fotosintesis berupa asimilat digunakan tanaman dalam fase vegetatif dan generatif. (Murdianingtyas et al. 2012). Antara bagian tumbuhan (daun, batang dan akar) tidak berbeda nyata terhadap pola tanaman agroforestri maupun monokultur, pada jenis $M$. arundinacea dan $M$. linearis juga tidak memberikan perbedaan yang nyata. Umur tanaman juga tidak berbeda nyata terhadap dua pola tanaman. Hasil analisis data menunjukkan bahwa tidak ada pengaruh nyata produktivitas umbi garut umur 6 dan 8 bulan setelah tanam (Tabel 4).

Produktivitas umbi garut pada pola agroforestri dan monokultur tidak berbeda nyata baik pada akar, batang, daun dan umbi. Hasil sidik ragam menunjukkan bahwa jarak tanam, dosis pupuk dan interaksi tidak berpengaruh nyata terhadap jumlah daun. Hal ini diduga karena belum terjadi persaingan dalam memanfaatkan cahaya matahari, unsur hara dan air sehingga jumlah daun yang terbentuk relatif sama dengan didukung data suhu maksimum pada bulan September yaitu $26.8^{\circ} \mathrm{C}$ dan suhu minimum pada bulan September yaitu $12.3^{\circ} \mathrm{C}$ serta rata-rata curah hujan tertinggi pada bulan November yaitu $14 \mathrm{~mm} /$ hari sedangkan rata-rata curah hujan paling sedikit pada bulan September yaitu $1.1 \mathrm{~mm} /$ hari (Gambar 2).

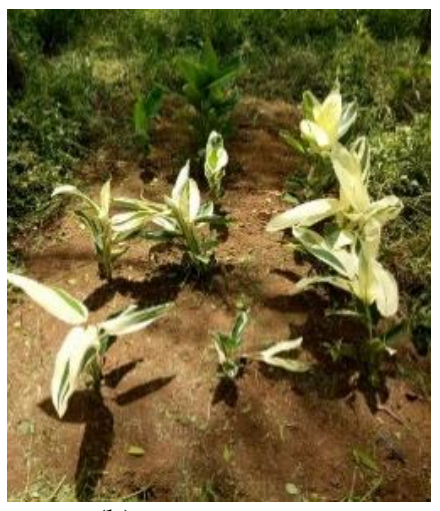

(b)

Gambar 1 (a) Umbi garut (M.arundinaceae) pola monokultur; (b) Umbi garut (M.linearis) pola agroforestri

Tabel 4 Hasil analisis produktivitas umbi garut

\begin{tabular}{lccc}
\hline \multicolumn{1}{c}{ Peubah } & Uji F & Agroforestri & Monokultur \\
\hline Daun & tn & $38.88 \mathrm{a}$ & $46.67 \mathrm{a}$ \\
Batang & tn & $40.60 \mathrm{a}$ & $54.82 \mathrm{a}$ \\
Akar & th & $30.54 \mathrm{a}$ & $42.72 \mathrm{a}$ \\
Umbi 6 bulan & th & $4.40 \mathrm{a}$ & $5.92 \mathrm{a}$ \\
Umbi 8 bulan & tn & $76.04 \mathrm{a}$ & $141.80 \mathrm{a}$ \\
\hline
\end{tabular}

(tn) : tidak berbeda nyata; $(*)$ : berbeda nyata pada taraf uji 5\%, angka-angka pada baris yang sama yang diikuti oleh huruf yang sama tidak berbeda nyata pada taraf uji 5\% (uji selang berganda Duncan).

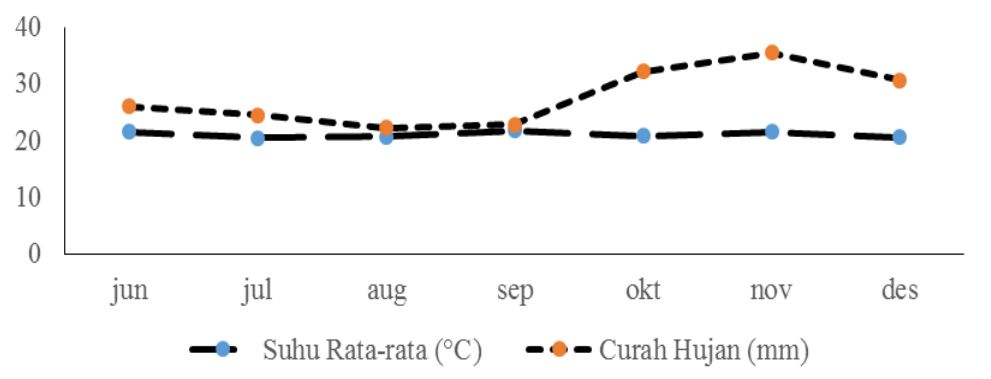

Gambar 2 Data curah hujan dan suhu 
3. Analisis fisikokimia umbi garut dalam pola agroforestri dan monokultur

Terdapat perbedaan hasil kimia umbi garut pada peubah kadar air dan kadar pati baik antar jenis umbi garut sendiri maupun dalam perbedaan pola tanam. Nilai kadar air 6 bulan setelah tanam paling tinggi pada pola tanam monokultur jenis M.arundinacea yaitu $25.81 \%$ sedangkan terendah pada pola tanam agroforestri jenis M.arundinacea yaitu $10.72 \%$. Umur tanam 8 bulan menunjukkan bahwa pola tanam agroforestri menghasilkan kadar air umbi garut (M. arundinacea) tertinggi yaitu $82.72 \%$, sedangkan nilai pati terendah dihasilkan oleh pola tanam monokultur M. linearis yaitu $73.02 \%$.

Nilai pati 6 bulan setelah tanam paling tinggi pada pola tanam monokultur jenis $M$. alinearis yaitu $76.35 \%$ sedangkan terendah pada pola tanam monokultur jenis M. arundinacea yaitu $52.15 \%$. Panen setelah tanam 8 bulan dilakukan, diperoleh nilai pati umbi garut tertinggi pada pola tanam monokultur jenis M. arundinacea yaitu $89.82 \%$, sedangkan terendah pada pola tanam agroforestri jenis M. linearis yaitu $82.46 \%$.

Pati termodifikasi memiliki peranan penting dalam bidang kimia, kosmestik, farmasi, dan industri pangan. Pati termodifikasi memiliki karakteristik yang lebih baik jika dibandingkan dengan pati alami dalam hal sifat adesif, kemampuan mengikat air, dan sebagainya. Saat ini penggunaan pati garut sebagai bahan baku dalam industri pangan telah banyak digunakan, namun belum ada yang memanfaatkannya menjadi pati termodifikasi (Noor 2016). Garut digunakan sebagai prebiotik karena terbukti dapat menekan pertumbuhan bakteri pathogen (Rosa 2010).

Produktivitas umbi garut lebih rendah pada pola agroforestri dibandingkan monokultur. Hal ini diduga terjadi karena adanya persaingan dalam mendapatkan hara pada lahan, diperlukan pembunbunan secara intensif. Perbedaan komponen kimia umbi garut 6 dan 8 bulan setelah tanam (Tabel 5).

Komponen unsur hara umbi garut pada pola tanam agroforestri dan monokultur terdapat perbedaan yang dapat dilihat pada Tabel 6 . Umur panen umbi garut 6 bulan unsur hara nitrogen tertinggi diperoleh pada pola tanam monokultur jenis $M$. linearis yaitu $0.62 \%$, sedangkan nilai terendah terdapat pada pola tanam agroforestri jenis $M$. linearis yaitu $0.48 \%$. Umbi garut umur 8 bulan diperoleh unsur hara nitrogen tertinggi pada pola tanam $0.52 \%$ dan terendah pada pola tanam agroforestri $M$. linearis yaitu $0.40 \%$.

Nilai protein 6 bulan setelah tanam paling tinggi pada pola tanam monokultur jenis $M$. linearis yaitu $3.88 \%$ sedangkan terendah pada pola tanam agroforestri jenis M. linearis yaitu 3.02\%. Umbi garut umur 8 bulan diperoleh unsur hara protein tertinggi pada pola tanam agroforestri jenis $M$. arundinacea $3.24 \%$ dan terendah pada pola tanam agroforestri $M$. linearis yaitu $2.47 \%$ (Tabel 6).

Tabel 5 Komponen Fisikokimia umbi garut

\begin{tabular}{lcc}
\hline \multicolumn{1}{c}{ Umur panen (bst) } & \multicolumn{2}{c}{ Komponen kimia } \\
\cline { 2 - 3 } 6 bln setelah tanam & Kadar air (\%) & Pati (\%) \\
Monokultur M.arundinacea & 25.81 & 52.15 \\
Monokultur M.linearis & 23.54 & 76.35 \\
Agroforestri M.arundinacea & 10.72 & 18.03 \\
Agroforestri M.linearis & 17.32 & 61.00 \\
\hline 8 bln setelah tanam & & 89.82 \\
\hline Monokultur M.arundinacea & 78.69 & 86.57 \\
Monokultur M.linearis & 73.01 & 82.46 \\
Agroforestri M.arundinacea & 82.72 & 83.93 \\
Agroforestri M.linearis & 73.68 & \\
\hline Sur
\end{tabular}

Sumber: Laboratorium PAU (Pusat Antar Universitas) IPB, Bogor.

Tabel 6 Komponen Unsur hara pada umbi garut

\begin{tabular}{lcc}
\hline \multicolumn{1}{c}{ Umur panen (bst) } & \multicolumn{2}{c}{ Unsur hara } \\
\cline { 2 - 3 } 6 bln setelah tanam & Nitrogen (\%) & Protein (\%) \\
Monokultur M.arundinacea & 0.54 & 3.40 \\
Monokultur M.linearis & 0.62 & 3.88 \\
Agroforestri M.arundinacea & 0.56 & 3.50 \\
Agroforestri M.linearis & 0.48 & 3.02 \\
\hline 8 bln setelah tanam & & 3.20 \\
\hline Monokultur M.arundinacea & 0.51 & 2.80 \\
Monokultur M.linearis & 0.45 & 3.24 \\
Agroforestri M.arundinacea & 0.52 & 2.47 \\
Agroforestri M.linearis & 0.40 & \\
\hline Suri
\end{tabular}

Sumber: Laboratorium PAU (Pusat Antar Universitas) IPB, Bogor. 


\section{SIMPULAN DAN SARAN}

\section{Simpulan}

Pertumbuhan mindi pada pola tanam agroforestri dan monokultur tidak memberikan perbedaan yang nyata, namun perbedaan yang nyata pada peubah akar mindi. Produktivitas umbi garut pada dalam pola tanam agroforestri maupun monokultur jenis Maranta arundinaceae dan jenis Maranta linearis tidak berbeda nyata. Nilai fisikokimia dan unsur hara pada umbi garut beragam, kadar air tertinggi pada pola tanam agroforestri $M$. arundinacea, namun kadar kadar pati pola tanam monokultur $M$. arundinacea. Nitrogen dan protein pola tanam agroforestri jenis $M$. arundinacea.

\section{Saran}

Diperlukan uji organoleptik untuk mengetahui nilai ekonomi yang lebih tinggi pada tanaman umbi garut.

\section{DAFTAR PUSTAKA}

Amalia. 2014. Umbi garut sebagai alternatif pengganti terigu untuk individual autistik. Warta Penelitian Pengembangan Tanaman Industri. 20(2): 30-31.

Ariyantoro H, Bahri S. 2014. Pengujian dosis dan frekuensi pemupukan urea terhadap pertumbuhan tanaman garut (Maranta arundinaceae L). Joglo 27(1): 242-247.

Darmawan S. 2016. Pertumbuhan mindi (Melia azedarach Linn.) dan produksi sorgum (Sorghum bicolor L.) dalam agroforestri [tesis]. Bogor (ID): Institut Pertanian Bogor.

Djaafar TF, Sarjiman, Arlyna BP. 2010. Pengembangan budidaya tanaman garut dan teknologi pengolahannya untuk mendukung ketahanan pangan. Jurnal Litbang Deptan 29(1): 25-33.

Hardjowigeno S. 2003. Ilmu Tanah Ultisol. Edisi Baru. Akademika Pressindo, Jakarta.

Hariyatno K. 2001. Peluang Dan Tantangan Pemasaran Kayu Mindi (Melia azedarach L.) : Studi Kasus di Bogor Jawa Barat. Info Sosial Ekonomi. 2(2): 77-86

Jirmanova J, Fuksa P, Hakl J. 2016. Effect of different plant arrangements on maize morphology and forage quality. $J$ Agriculture 62(2):62-71. DOI: 10.1515/agri-2016-0007.

Koswara S. 2013. Teknologi pengolahan umbi talas. Southest asian food and agriculture science and technology (SEAFAST) centre research and community service instution bogor agricukture university. Bogor (ID): IPB Press.

LPT (Lembaga Penelitian Tanah). 1983. Penuntun Analisa Fisika Tanah. Lembaga Penelitian Tanah. Badan Penelitian dan Pengembangan Pertanian.
Mattjik AA, Sumertajaya IM. 2013. Perancangan Percobaan dengan Aplikasi SAS dan Minitab. 2nd Ed. Bogor (ID): IPB Press.

Mayrowani H. 2012. Pengembangan Pertanian Organik di Indonesia. Bogor (ID): Pusat Sosial Ekonomi dan Kebijakan Pertanian.

Murdianingtyas PH, Indradewa D, Gunadi N. 2012. Pengaruh pengurangan daun terhadap pertumbuhan dan hasil dua varietas paprika (Capsicum annumvar. Grossum) hidroponik. J Vegetalika. 1(3): 19-33.

Noordwijk MV, Mulia R, Hairiah K. Estimasi biomasa tajuk dan akar pohon dalam sistem agroforestri: analisis cabang fungsional (functional branch analysis, fba) untuk membuat persamaan alometrik pohon. Bahan Ajar 8. Diunduh : [http://www.worldagroforestry.org/sea/Publications/ files/lecturenote/LN0038-06.pdf] 13-05-2018: 136152

Nurhayati H, Yusron M, Gusmaini. 2007. Optimasi populasi tanaman garut (Maranta arundinaceae) di bawah tegakan tanaman perkebunan. Bogor (ID): Litbang Pertanian.

Oktavia D, Setiadi Y, Hilwan I. 2014. Sifat fisika dan kimia tanah di Hutan Kerangas dan Lahan Pasca Tambang Timah Kabupaten Belitung Timur. Jurnal Silvikultur Tropika. 5(3): 149-154.

Rosa N. 2010. Pengaruh penambahan umbi garut (maranta arundinaceae l) dalam bentuk tepung dan pati sebagai prebiotik pada yoghurt sebagai produk sinbiotik terhadap daya hambat bakteri Escherichia coli. Universitas Diponegoro. Semarang.

Sarno. 2009. Pengaruh kombinasi NPK dan pupuk kandang terhadap sifat tanah dan pertumbuhan serta produksi tanaman caisim. J Tanah Trop. 14(3): 211219.

Sudomo A, Santosa HB. 2011. Pengaruh media organik dan tanah mineral terhadap pertumbuhan dan indeks mutu bibit mindi (Melia azedarach L.). JPHK. 8(3): 263-271.

Suganda H, Rachman A, Sutono. 2014. Petunjuk Pengambilan Contoh Tanah. Bogor (ID): Balai Penelitian Tanah.

Suhardi S, Sabarnurdi SA, Soedjoko HD, Dwidjono, Minarningsih, Widodo A. 1999. Hutan dan Kebun sebagai Sumber Pangan Nasional. Jakarta (ID): Departemen Kehutanan.

Wardani A. 2017. Pertumbuhan mindi (Melia azedarach L.) dan kedelai (Glycine max. L.) secara organik dalam sistem agroforestri [tesis]. Bogor (ID): Institut Pertanian Bogor.

Wijayanto N, Nurunnajah. 2012. Intensitas cahaya, suhu, kelembaban dan perakaran lateral mahoni (Sweitenia macrophylla King) di RPH Babakan Madang BPKH Bogor, KPH Bogor. J Silvikultur Tropika 3(3): 8-13.

Wijayanto N, Rifa'i M. 2010. Pertumbuhan Gmelina arborea Roxb. pada Beberapa Pola Agroforestri. Jurnal Silvikultur Tropika. 1(1): 29-34. 